\title{
"Trivial" Matters: Some Historico-Pedagogical Reflections
}

\author{
THOMAS CONLEY University of Illinois
}

Key Words: Education; grammar; logic; rhetoric; Trivium.

\begin{abstract}
The enduring persistence of the examples and exercises used in handbooks of the traditional arts of the Trivium (grammar, logic, and rhetoric) suggests that they were recognized as perennially effective as ways to inculcate intellectual virtue in many generations of students. Yet an examination of those examples and exercises suggests that only the ones in the rhetoric curriculum were able to resist acquiring the bad habits of the sister arts of grammar and logic. Sensitivity to facts and meanings and the ability to manipulate theses do not by themselves guarantee the formation of active and competent citizens. Only when those virtues are combined in the interests of eloquence - the art of disciplined expressioncan they be fully realized.
\end{abstract}

From Hellenistic times on, educators have agreed-or so it seems-that three basic arts or disciplines together provide the basis for what might be called cultural literacy and critical thinking: grammar, dialectic, and rhetoric. On occasion, those old schoolmasters disagreed on how those arts ought to be ranked in order of their importance and on whether, for instance, rhetoric ought to be taught before or after dialectic. The various claims advanced are usually grounded on considerations of theoretical rigor and elegance of curriculum design, or by appeal to different ideal "products" that would emerge from the schoolroom. But there is little disagreement-at least, before Bacon's "New Instauration"-that these three arts, the Trivium, and the training in them students got at the hands of their masters are indispensible in the formation not only of erudition and social savoir-faire, but of character as well.

Conceived in terms of what they were intended to deal with and what capacities they aimed at producing in the student, we might characterize the arts of the Trivium as involving three parallel and overlapping "arts." The first is an "art" of recovery that concerns questions raised in the interpretation of texts and experience and in the interpretation of facts stated and meant in discourse. The intellectual and, by extension, moral virtue inculcated by the art is a disciplined sensitivity to the significance of language and the connections between thoughts. The exercises related to these consist of construing the "grammatical" sense of texts and of producing explanations of those texts (enarrationes in the Latin tradition).

The second "art" is an art of "discovery," or invention, which modifies or abandons certainties of prior interpretation when they become involved in inconsistencies or when they themselves present problems. The intellectual virtue resulting from the trained ability to discover (or "invent") new "facts" by the heterogeneous combination of concepts and terms and transforming them into places or relating them to commonplaces is a sort of disciplined creativity. The exercises related to this art call upon the student to generate contrary or contradictory or comparable theses and the arguments to support them in the setting of disputation or controversia designed to uncover inconsistencies and ambiguities and their implications and resolutions, and test their demonstrations and justifications. 
The third "art" is concerned with tracing the implications and consequences of any thesis, moving from thesis to thesis by finding ways of treating different accounts as variations on a theme. This art is an art of presentation grounded in the connections between theses and themes akin to the medieval ars disserendi. Insofar as it enables one to set forth and analyse sequences and consequences using methods which establish connections between propositions and problems of life and action, it comprises powers of disciplined expression, or "eloquence."

Such high-sounding arts and the disciplines they are imagined to impart are all admirable enough as goals, one might suppose. But the crucial question for the schoolmaster is not so much "To what end?" as "By what means?": that is, what sorts of things ought one to teach in pursuit of those goals? On the matter of curriculum content for each of the trivial arts, there seems to have been a consensus that today's educators might find incredible, for the "matter" taught in the grammar, dialectic, and rhetoric courses remained remarkably stable for centuries. This is apparent from the many extant handbooks composed for teachers in those subjects in late Antiquity and in the Middle Ages, both in the Latin West and the Greek East. The almost unchanging nature of the progression from elementary to advanced exercises and examples that one finds in the handbooks accessible to us might be construed as betraying a singular lack of imagination or creativity. It is usually those ignorant of the available evidence, however, who so construe that material (for instance, those who are inclined to view the middle ages as a gigantic parenthesis between the distant past and the recent present). The alternative perspective would invite us to regard the persistence of the examples in the handbooks as a recognition of their perennial effectiveness, tested by generations of masters, in training students to be sensitive, creative, and eloquent. From that perspective, it might be in order to look briefly at what those examples and exercises were about, why they were assigned and discussed, and where they tended to lead students in their lives in and out of school.

\section{Grammar}

The grammatical art, as it was conceived from Late Antiquity through the Middle Ages, extended far beyond what is currently considered to constitute the study of grammar. It is, one might say, closer to what is now called "language arts." Its office was to deal with ta grammata, "the letters," so as to recover from them all that could be recovered of that which they had saved from oblivion. The definition set down by Dionysius Thrax enumerates six parts of the art: 1) "reading aloud expertly, with due attention to the music of the words"; 2) "interpretation (exegesis) as determined by the poetic tropes inhering in the language"; 3 ) "ready explanation of obsolete words and of matters of fact alike"; 4) "discovery of etymologies"; 5) "determining the class to which word forms belong"; and 6) "literary judgment (krisis)." The order as set down here does not reflect the actual order of priority in which the various parts had to be taught, as, for instance, 3 and 2 would obviously have to be mastered before one could move on to 1 and 6.

The most elementary stages of instruction were carried on by means of katekhesis (whence "catechism") by question and answer - as in the "lesson" alluded to by Arrian (Epict.Diss.2.19): "Q: Who was the father of Hector? A: Priam. Q: Who were his brothers? A: Alexander and Deiphobus"; or in the Epimerismoi on Psalms composed by the Bulgarian Hirovotsk (Choiroboskos) in the ninth century [cf. ed. of T. Gaisford (Oxford,1842).]: "Parse katerraxas [at Ps 101:3]." "First aorist, from katarasso." For Ps $17: 9$ and 
11, to sort out an apparent pleonasm: "Why both 'gnaphos' and "nephele"?" "These denote different kinds of clouds." "What does the word kithara [at Ps 150:3] mean?" "Kithara: from kinein eis erota [to move to passion] or from kinein tous thairous [to open the gates]."

Hirovotsk did not subject his students to such close questioning just because they were Bulgars, for whom Greek was a second language. Psalms was an elementary text in Byzantine schools that all young students of grammar were expected to learn to understand. And if one expects to be able eventually to "read aloud expertly," one had better get such apparently trivial things straight.

More advanced grammar went beyond the interpretation of particular words and phrases to the task of interpreting longer passages or even works as wholes, so as to be able to provide plausible enarrationes of them. For these ends, the ability to understand where tropes appear, and what is intended by them, becomes particularly useful. In a dialogue composed by Conrad of Hirsau (d.c.1150), we find the following exchange:

TEACHER: ... When you lay upon me the task of expounding secular literature you forget the words of the prophet.

STUDENT: What does he say?

TEACHER: "The Lord has destroyed the tongue of the sea of Egypt" [Isaiah $11: 15]$.

STUDENT: What does this mean?

TEACHER: The tongue of the sea of Egypt represents the teachings of worldly knowledge, which is hardly ever, or perhaps not at all, without the obscurity which derives from sin or worldly vanity....

The same approach can uncover the meaning of a work by analysis of its title alone, as the introduction by Remigius of Auxerre to his expositio on the Paschale carmen of Sedulius Scottus (9th C.) explains:
According to Servius, the term titulus comes from "Titan," that is, the sun ... and just as the rising sun illuminates the whole world, so the titulus illuminates the work that follows. ${ }^{3}$

Thus we find in the "accessus" literature commentators on Boethius laboriously expounding, word by word, the meaning of the Consolations of Philosophy by analyzing the title as it appeared in the MSS. before them, Anicii Manilii Severini Boetii ex magno officio viri clarissimi et illustris exconsulum ordine atque patricio liber philosophicae consolationis primus incipit. "Severinus" refers to the severity of Boethius' judgments; "Boethius" is from a Greek word meaning "helper," and so on."

Indeed, this method of analysis also works for entire genres. As Conrad explains later in the dialogue cited before,

The verse form in which drinking parties
with their accompanying amusements are
described is "lyric." It gets its name from
"apo to lirin" [sic], that is from "variation,"
hence "delirius" ["crazy"]....

And similarly, in a preface to the works of Theodulus from about the same time, we read,

The word "Ecloga" was derived from goats, for "egle" in Greek is "capra" in Latin, while "logos" is "sermo," hence the word "ecloga" means a discourse relating to goats."

Read against a background of the constant refrain heard from both grammarians and their critics-e.g., Aulus Gellius, who saw in grammarians' notebooks a fair number of "infantile puzzles" (Noctes 14.6); or Sextus Empricus, who complains about "men scarcely able to put two words together rightly (dexioss) who are ready to denigrate the great masters of clear and correct expression" [Ag.Gram. 1.98 (ed. Janácek)]-such explanations as those of Conrad and his fellow scholars seem hardly the sort of thing that would insure that schoolboys should be able to handle the texts set before them. What we see there, 
and indeed repeatedly in a tradition that runs down from Servius through Isidore of Seville to Remigius and thence into the twelfth century, is hardly the sort of "reading" that guarantees that the tropes and figures will be properly understood; and even less the sort of thing that seems designed to produce a disciplined sensitivity.

One might think these exceptions to the rule, or aberrations of erudition, that are thankfully limited to communications between masters and students. This sort of reasoning made its way into some very real disputes in the twelfth century, however. The drive by such reformers as Peter the Chanter to "preach to the people," along with the rising influences of the mendicant orders, brought about a popularization of the old four-level method of allegorical exegesis that had previously been pretty much restricted to an exegetical élite. What we find is an increasingly opportunistic use of appeals to the "spiritual sense" of scripture in debates about, e.g., privilege and "territory." So, for instance, in Cister"cian polemics against the strict observance of the Rule of Benedict ("Work and Pray"), Clunaic rules are attacked by means of an elaborate "reading" of the story of Jacob and Esau (Genesis 27:1ff.) that identified the Cistercians with Jacob and the Clunaics with Esau; or rebutted by a reading of the Noah story in which the Benedictines are identified with the family of Noah and any others with the animals occupying the lower decks of the Ark. In the same vein, we find a defense of monks holding outside jobs for pay, generally forbidden, by means of a "spiritual" reading of Exodus 16:16 that has the clerks identified with the Israelites getting their gomer of manna.

If the eclogues of Theodulus can be read as goat-poems, and Exodus used thus to defend forbidden income, grammar, it would seem, makes anything possible, as indeed it can once the entire burden of interpretation is placed on the possible meanings of words and titles. The "method" $^{\prime \prime}$ in these examples seems to dispose of the ordinary determinations of the meaning of a text by recourse to the syntactic possibilities of the language and the attested semantic values given to words by usage and analogy, and to promote instead a "calculus" accumulating all the hidden meanings of words to a point where they all "add up" to a meaning: "tout se tient." In this respect, medieval grammar aproaches the excesses of what has come to be called "deconstruction" and of the "post-modern" mentality so brilliantly satirized by Umberto Eco in Foucault's Pendulum (cf., especially, at pp.517ff.), instead of the disciplined sensitivity it sought ideally to inculcate in those trained in it. And if it is not inevitable that this should happenhappily it is not-it is all too easy.

\section{Logic}

"Logic" is of course a refinement of the standard course in dialectic taught to students from Hellenistic times. Dialectic originally included principles for both the invention and judgment of theses and arguments, the subjects (respectively) of Aristotle's Topics and Analytics. The latter has in recent years been designated, mistakenly, as the fons et origo of Logic as it is now known.

Thus, Lukasiewicz and Boehner demonstrated the "invention" of modus ponens by Aristotle. But in doing so, they distorted the dialectical scenario Aristotle had in mind even in the Prior Analytics. So, at AnPr 1.23 and 44, Aristotle seems to recognize the rule of logical inference commonly called modus ponens in his treatment of hypothetical arguments there. Wishing to prove $Q$, he points out, one adds $\mathrm{P} \rightarrow \mathrm{Q}$ as a hypothesis, "proves" $\mathrm{P}$, and thus "proves" Q. But Aristotle represents this argument in a dialectical context, in which the hypothesis $P \rightarrow Q$ is a matter of agreement between two opponents. In that scenario, the opponent who denies $\mathrm{P}$ but concedes $P \rightarrow Q$ is declaring that a proof of 
$Q$ is unnecessary once $P$ has been demonstrated; he is not providing a premiss which might be used as proof of $Q$. Thus, Aristotle does not in fact conceive of modus ponens as a rule of logical inference. It is much more accurate to credit the Stoics for the isolation of logic from dialectic than to burden Aristotle with it. And that is where we might also place the blame for centuries of pedagogy that seems to have made it inevitable that the examples and exercises should become inherently self-consuming.

By "self-consuming," I refer to the visible tendency in the entire tradition from Boethius up to the thirteenth century (and beyond, even to the present) to analyze natural language in such a way, and to such an extreme, as to void it of any meaning. As dialectic turned progressively away from the scenario of disputatio that had originally defined its duties and promise, and came to concern itself exclusively with judgment at the expense of that part of the art that taught the arts of dialectical invention, its focus and the consequent vehicles for teaching it became exceedingly-perhaps excessively-narrow and trivial.

In one very visible strand of the history of dialectic in the middle ages, we see a progression in which dialectic is first detached from its disputation scenario as it is brought in to control the excesses of grammar and then itself abandoned as teachers turned to formal logical considerations to stem the growing confusions brought about by the use of dialectic as a corrective to grammar. In the first "phase," for instance, we find interpreters of Scripture puzzling over the apparent contradiction between the verse in Matthew (5:34) which reads, "ego dico vobis omnis non iurare" and Psalm 118:106, "iuravi et statui custodire..." This was relatively easy to dispose of, as "iurare" is attested as meaning both "swear lightly" and "take a solemn vow." But what does one do with Matthew 2:19, which tells us the Christ returned from Egypt after Herod died and Luke 3:1, 19, and 21 , all of which say that Christ was baptized "under Herod"? The contradiction here is just like the one in the old example from dialectic dealing with the apparent contradiction "Cato est fortis"/ "Cato non est fortis": 1) "Cato" is the name of (at least) two different individuals; 2) "fortis" may refer to both mental strength and physical strength. The importance of being able to subject the excesses of grammar to the discipline of dialectic became especially clear in the mid-11th century in the important controversies over eucharistic reform that arose as a result of Berenger of Tours's attacks on conventional theology. In the face of Berenger's exploitation of the resources of the sort of grammatical analysis we saw in the teachings of Remigius and Conrad, his pupil Lanfranc came to the rescue with an arsenal of dialectical distinctions and canons. Hence, the elaborate apparatus brought in a generation later supporting the analysis of propositions by means of loci communes (part, whole, adjunct, opposite, etc.) to hunt down the principles on which arguments derived from different kinds of propositions might be discussed comes as no surprise-as in the "Introduction to Dialectic" ascribed to William of Champeaux, for instance. ${ }^{8}$

It is in this context that the seemingly endless worrying over propositions like "Socrates est asinus" or "Socrates est albus" needs to be put if medieval logicians are to be rightly appreciated. Yet, even granting that such apparently trivial concerns must be comprehended in the context of the disputes they were meant to resolve, it soon becomes evident that with dialectic, as with grammar, every discipline seems to contain within itself the seeds of its own dissolution. This seems to be the case in the famous "canis currit" example one encounters in the commentaries on the Sophistic Elenchi of Aristotle in the 12th and 13 th centuries.

At $S E$ 4, 165b25ff., Aristotle divides fallacies into two categories: in re and in 
dictione. Medieval commentators following Galen, recognised that fallacies in dictione arose from a plurality of senses (multiplicitas, "polysemy") in some segments of speech: either in single words or in groups of words, the polysemy being either actual, potential, or imaginary.

In the "running dog" example, it was first observed that "canis" is in itself equivocal, as it can denote 1) the barking animal (animal latrabile), 2) a sea-creature (marina belua, the "dog fish"), or 3) a certain star (caeleste sidus, the Dog Star, Sirius). Hence a syllogism such as "Every dog can run; Sirius is a dog; ergo, the heavenly star can run" may not be able to persuade anyone that Sirius has feet. But if one cannot explain why it is formally unsound, logic breaks down.

The problem is compounded when one takes the whole proposition "canis currit" for analysis. If "canis" is equivalent to the conjunction of [barking animal+seacreature+star], then the subject of "canis currit" is plural and should require "currunt," not "currit." But "canis currunt" is ungrammatical, in turn, because it loses sight of the fact that "canis" may refer to the class "dog," which, while it may have different species, still takes the singular. Therefore, "currit" is correct after all. In addition, "canis" can also denote "the dog," hence "currit" is correct-this last refinement explaining the Scholastic invention of a definite article for Latin where none had existed before. ${ }^{9}$

In the end, this proposition proved to be open to almost endless analysis (based on a peculiarity of the Latin, by the way; the same problems would not have arisen so easily in Greek); and to complicate things further, there were even more complicated cases. What do we do, commentators asked, with a proposition containing the word amor? Is it a noun ("love") or a verb ("I am loved" [sic])? To Aristotle's initial distinction and to Galen's further ones, yet another-between modus habitus and modus fieri-had to be introduced to "make sense" of the proposition in preparation for determining whether it be true or false. And with such propositions as "Rex est parisinus" - the truth conditions of which are fairly easy (only if, as the author of Digby 174, fol.226v tells us, "Rex"="Ludowicus," i.e., Louis VII [1137-80]; shades of Russell's "The present King of France is bald"!)-we get into deep trouble as soon as we consider the modal variations.

It is in relation to such conundrums that we can appreciate Anselm of Canterbury's (d.1109) deprecation of traditional grammar in the suggestion he makes that we forget about usage and experience and simply expel any substantive reference from adjectives; the suggestion that, given the difficulties of distinguishing the contrary and the contradictory of a simple proposition like "homo est iustus" - what after all is the difference between "nullus homo est iustus" and "homo non est iustus"? - along the lines of Aristotle's Square of Opposition, we make nullus into a free logical operator; or Robert Kilwardby's insistence that a materially deficient argument could in fact be a syllogism if we concentrate on the "mental" grammar behind it. ${ }^{10}$ Rather than continue to wrestle with the problems that arise at the intersection of grammar and dialectic, these thinkers seem to be saying, let us once and for all separate problems that are truly logical from problems that stem from experience and usage.

The turn to the "truly logical" in the middle ages anticipated developments much later-in Frege's work, the Principia of Russell and Whitehead, Carnap, and Tarski-where the same curious sorts of examples seem to preoccupy those who see their mission as restoring rationality to the world. "Efforts to determine the minimal conditions of formal validity and a putative escape from non-sense have in this century given us examples no less absurdly trivial than the energy expended in the twelfth century, to the point where "critical 
thinking" is taught in books replete with "problems" for students to solve that reduce thinking to what might be called "Bill and Henry exercises": "If Bill can cut a pile of wood in ten days, and Henry can cut a pile of wood in five days, how long will it take both of them together to cut the pile of wood?" Try to transfer the skills acquired from such problem-solving to problems in ethics, for instance, and you get the sort of "Ethics" that uses as its paradigm such thorny questions as "Should I go to the tea shop today?" Even the most penetrating critic of that way of thinkingWittgenstein-found it natural to speak in the idiom concocted by Russell: note his meditations on thinking and speaking in The Blue Book [New York, 1958] which puzzle over whether King's College is really burning (31) or who was meant when someone said "Napoleon was crowned in 1804" (39). Of course, the difference between Wittgenstein and his erstwhile master was that Wittgenstein went to the movies seriously; Russell did not. Yet not even that enabled him to feel comfortable dealing with large problems except in tiny terms.

\section{Rhetoric}

The rhetorical tradition behind the enkyklios paideialartes liberales curriculum was inspired by the ideals set out first by Isocrates, elaborated and specified by Cicero, and pedanticised by Hermogenes in the East and Quintilian in the West. The aim of the teachers of rhetoric was to prepare students to pursue careers in the public world, to become vires boni dicendi periti. Yet what we see on looking at the elementary instruction given in the progymnasmatic exercises is evidence of a long succession of generations of students elaborating on the same quotation ascribed to Isocrates ("The root of education is bitter, but the fruit is sweet."), recounting the same stories about donkeys and foxes and adulterous divinities, working up comparisons between spring and summer, and inventing arguments about laws that never existed.

What is more, there are no "phases" in this history, it seems. The same texts - the Progymnasmata of Hermogenes and Aphthonius in the Greek East, and Priscian's Praeexercitamenta (a Latin translation of Hermogenes' Progymnasmata) in the Latin West-were taught and the same exercises assigned continuously for over a thousand years. We must be careful, however, to notice that, despite the apparently trivial and unoriginal nature of the examples taught in the rhetoric curriculum, the lessons they imparted were far from trivial. In the final analysis, instead of promoting parodies of literary imagination and analytic precision (as the exercises in grammar and logic were wont to do), these elementary exercises inculcated thoroughness, rigor, and disciplined expression.

We cannot go into this in much detail here, but two of the standard exercises will illustrate what $I$ am talking about. The first, which required students to compose narratives of various kinds, including myths and fables, invariably set fantastic and fabulous themes: Medea gone mad, or some tale from Aesop. ${ }^{12}$ The constraints on these compositions were stringent, however, for the student had to make sure to answer a whole range of questions in developing his theme: who? what happened? why? where? what were the events leading up to the one recounted? what were the consequences? etc., etc. By composing many such themes, students would have been trained always to analyse in detail the episode, its characters, and their motives in a way ideally suited to prepare them for later formal training in how to analyse a legal case by means of the stasis-system and the standard lines of argument (topoi, loci) that went with it.

In a second exercise, the so-called chreia, the student was assigned a smart saying 
(such as that of Isocrates) and told to develop it, showing in the end its application to daily life. The pattern of development is set out in the version by Hermogenes [ed. Rabe, pp. 6ff.]: 1) first, praise its author and amplify; 2) then recite the saying and amplify; 3 ) then supply a rationale (aitia); 4) then make the argument "from the contrary"; 5) then "by analogy"; 6) then give an example and/or cite an authority; and then add 7) the exhortation (paraklesis) "to the effect that it is necessary to heed the one who has spoken..." Clearly visible in this progression is an embryonic formal oration with the conventional parts: Exordium (step 1); Partition (2); Argument and refutation (3-6); and Peroration (7). After dozens of attempts to master the chreia-exercise, the student would have become thoroughly habituated to speaking thus fully about any thesis assigned.

After the successful completion of the elementary exercises, the rhetoric student would go on to the next stage: composing and delivering declamations-first rather short ones, then quite long and involved ones-on assigned themes. Collections of sample declamations from both the Greek East and the Latin West, like the progymnasmatic literature, continued to be used in schools for well over a thousand years. The so-called "Minor Declamations" attributed to Quintilian (only 144 of 388 can confidently be said to have been composed in Quintilian's time) persisted through Late Antiquity into the 9th century (Montpellier $\mathrm{H} \mathrm{126)}$ and into the Renaissance. ${ }^{13}$

And like the elementary exercises, these short declamations deal with a number of bizarre themes: cannibalism (\#369), drunkenness and rape (309), parricide (377), poison and love potions (385), torture (269), and philosophers-mainly foolish and lazy (vani et otiosi) (268). All, even those that seem to deal with historical events (e.g., \#323), are quite fictitiousquite deliberately so, as it was thought im- portant to be able to teach students to develop arguments without cluttering their heads with historical facts. All build on the sorts of lessons taught by the elementary exercises: vivid descriptions and analysis of circumstantiae, put to the service of clear and organised thinking. While some are mechanical exhibitions of the issues treated in stasis-theory ${ }^{14}(321)$ and others variations on a theme (e.g., 252 and 370 ), a great many turn on rather sophisticated questions of letter $v s$. intent and of the related matter of aequitas ("equity").

The "minor" declamations preserved in Seneca's Colores and in the collections attributed to Quintilian are quite short (maximum of one printed page), probably represent no more than outlines to be consulted by teachers, and so don't give us a very good idea of what students were actually expected to be able to do with those exercises. The "major" declamations, which tend to be much longer, show vividly what could be expected of a student assigned to argue, for instance, on behalf of the father in "The Case of the Beached Corpse" or to prosecute the agent sent to buy food in "The Case of the People who Ate Corpses." 15 In such exercises, all the skills of invention, arrangement, and expression and command of all the intricacies of argumentation and emotional appeal are brought to bear with a view toward successful defense and prosecution in cases where the law provides no clear way to see that justice is done and thus must be argued by appeal to the norms of aequitas.

What is special about questions of aequitas is the fact that they are precisely those questions that are not resolvable by recourse to close readings or formulaic applications of the law-that is, the sorts of questions that pose genuine problems for advocates and political speakers. Any mediocre student could run a causa through the prescribed steps; but only the cleverest could deal adequately with issues that fell outside the prescriptions. Cases involving 
aequitas are both the ones that pose the most interesting problems (cf., e.g., Cicero, De oratore 1.173; Quintilian, Institutes $5.10 .118,6.5 .5$, etc.) and the ones that judges take the most pleasure in (Quintilian 7.1.63). To a professional orator, the aequitas themes in the declamation class were easy, compared to real cases (De orat.2.100); yet teachers and experienced workers in the public sphere alike agreed that there was no more effective way than composing declamations-even if on bizarre and silly themes-to train a pupil to make a speech that had a shape, and to have that shape as a whole in his head as he spoke the parts.

Such declamations persisted as parts of the rhetoric curriculum, it appears from the record of manuscript transmission, well into the middle ages-until dialectic was decreed (as in Paris, in 1215) to be the dominant element in the Trivium. At that point, the skills inculcated by the more advanced exercises in rhetoric came to be taught in the specialized courses in notarial arts, poetic composition, and sermon composition. The elementary exercises remained pretty much intact. One is tempted to conclude that the reason for the continuity of the traditions of rhetorical pedagogy was the recognition by teachers, from Quintilian and Hermogenes on, that the standard exercises in rhetoric did indeed teach what they were supposed to. However fanciful the themes, the classroom developments of the fable and the chreia and the declamations never ceased to be grounded in the particulars of speaker, subject, and audience; and however rigid their forms seem to have become, they never allowed themselves to be reduced to the simplicities of inferential schemata. In these respects, the rhetorical exercises were able to resist acquiring the bad habits of the exercises of the sister arts of grammar and dialectic and thus continue to succeed in inculcating the virtues of thought and action the "trivial" arts were intended to inculcate.

\section{Conclusion}

If this "reading" of the history of "trivial" examples is plausible, what lessons might we draw from it today, when the politics of education has of late put such an enormous stress on cultural literacy (and "numeracy," alas) and the sometimes related desire to cultivate critical thinking? It has become a matter of virtual consensus that these are not stressed enough-indeed, have often been ignored altogether-by those entrusted with the formation of the young into intelligent and responsible adults. But it would be an understatement of colossal proportions to say that there is very little that is new about either the diagnosis or the indicated therapy for today's educational dis-ease. Those concerns are as old as education itself; and the solutions urged on us today are hardly any younger. That is the first lesson.

The second lesson might be put this way: "Cultural Literacy" seems lately to have become a matter of supplementing interpretative methods ("hermeneutics," "critical theory") with a collection of factoids (often alphabetically arranged) that together will enable students to comprehend the meanings buried in the lines of print in front of them. Curricula built in the interests of "Cultural Literacy" thus seem to bear an uncomfortable resemblance to the sort of grammar that medieval masters and students found so easy to abuse. Many "Critical Thinking" curricula, likewise, seem to share aims and methods in common with the dialectical reformers of the middle ages; and appear to share also the potential for trivialization that dialectic taught as part of the Trivium fell prey to. By themselves, then, sensitivity to facts and creativity in manipulating theses do not guarantee in themselves the formation of active and competent citizens. Only when those virtues are combined in the interests of eloquence-the arts of disciplined expression-can they be fully realized. 


\section{Notes}

1 The following characterization of the "trivial" arts is much indebted to R.P. McKeon, "Character and the Arts and Disciplines," Ethics 78 (1968/9), 109-23.

2 Conrad de Hirsau, Dialogus super auctores, ed. R.B.C. Huygens, Collection Latomus 17 (Brussels, 1955), p.15.

3 "Fragmenta remigii," ed. J. Huemer CSEL X. (Vienna, 1885),314ff.

4 Accessus ad auctores, ed. R.B.C. Huygens, Collection Latomus 15 (Brussels, 1954) p.41f. Compare Dialogus (cited above, n.2), p.43.

5 Dialogus, p.17.

6 Dialogus, p.33.

7 Beryl Smalley, "Use of the 'Spiritual' Sense of Scripture in Persuasion and Argument by Scholars in the Middle Ages," Recherches de théologie ancienne et médiévale 52 (1985), $48-63$.

8 The text, at Vienna Phil. Lat. 24992, fol.23$32 \mathrm{v}$ (see fol. $30^{\mathrm{v}}-31^{\mathrm{v}}$, on simple hypotheticals), can be found in L. de Rijk, Logica modernorum (Assen, 1967) 2:1, pp.134ff.

9 On this example, see S. Ebbesen, "Grammar in Elenchi Commentaries," Historiographia Linguistica 7 (1980), 53-68.

10 The text from Anselm is at De grammatico 16-19, $P L 158,575$ ff. On the other examples, see Osmund Lewry, "Grammar, Logic, and Rhetoric," in The History of the University of Oxford I (ed. J. Catto; Oxford, 1984), 401-33.

11 The consequences and inherent problems of the formalism behind that preoccupation are discussed by Chaim Perelman in "Logic, Language, and Communication," in The Idea of Justice and the Problem of Argument (London, 1963), pp. 143-53.

12 Later progymnasmata for use in Byzantine schools - the examples composed by Nikephoros Basilakes in the 12 th century, for instance - set themes from the Bible, but always involving episodes never actually recounted there. See Niceforo Basilace: Progimnasmi $e$ Monodie, ed. A. Pignani (Byzantina et neohellenica neopolitana 10 [Naples, 1983]), "Ethopoeiae" 1-13 (pp. 13983; notes at pp. 313-38).

13 See the edition by D. Shackleton-Bailey (Leipzig, 1989).

14 Some idea of the richness of this method of analysis and invention of lines of argument can be gathered from the fact that, theoretical$\mathrm{ly}$, it is possible to generate 256 arguments on any "issue of fact" by pursuing all the possible combinations of the 16 loci concerning persons and deeds, as in, e.g., Cicero's De inventione 1.24.34ff.

15 Nos. 6 and 12; cf. the versions in L. Sussman, The Major Declamations Ascribed to Quintilian: A Translation, Studien zur klassischen Philologie 27 (Frankfurt, 1987), pp. 69-84, 145-64. The educational virtues of such declamation exercises-in particular, their treatment of aequitas - are discussed by $\mathrm{M}$. Winterbottom, "Schoolroom and Courtroom," in Rhetoric Revalued, ed. B. Vickers (Binghamton, NY, 1982), pp.59-70.

THOMAS CONLEY

DEPARTMENT OF SPEECH COMMUNICATION UNIVERSITY OF ILLINOIS

702 SOUTH WRIGHT STREET, \#244

URBANA, IL 61801 